\author{
Janusz Ustupski \\ Zakład Geografii Regionalnej \\ Instytut Geografii \\ Akademia Pedagogiczna w Krakowie
}

\title{
Przedsiębiorczość w otoczeniu Tarnowa
}

Prawie siedemnastoletni okres funkcjonowania gospodarki wolnorynkowej w Polsce stwarza sytuację, w której konieczne są systematyczne badania nad rozwojem przedsiębiorczości w poszczególnych regionach. W ostatnich latach w wielu miejscowościach obserwujemy dynamiczny rozwój sektora małych i średnich przedsiębiorstw (MSP). Powstają ośrodki, które wpływają na rozwój procesów przedsiębiorczości w otoczeniu i z upływem czasu zaczynają oddziaływać na obszary dalej położone, co stwarza dogodne warunki rozwoju przedsiębiorczości w całym regionie. Wraz ze studentami Wyższej Szkoły Biznesu w Tarnowie ${ }^{1}$ autor podjął próbę analizy rozwoju przedsiębiorczości w rejonie Tarnowa, z uwzględnieniem jej aspektu przestrzennego. Przedsiębiorczość $\mathrm{w}$ ujęciu przestrzennym to funkcjonowanie przedsiębiorstw i firm na tle walorów naturalnych i antropogenicznych regionu. Przedsiębiorczość, pobudzana i wspomagana przez władze samorządowe i stowarzyszenia lokalne, przejawia się działaniami zmierzającymi do udoskonalenia produkcji, usług, systemu dystrybucji oraz wzrostu efektywności poszczególnych podmiotów gospodarczych.

Uznając, że badania nad przedsiębiorczością przedsiębiorstw i firm w regionach są uzasadnione, można sformułować następujące problemy badawcze:

- Jakie czynniki wpływają na rozwój przedsiębiorczości?

- W jakich dziedzinach występują przejawy przedsiębiorczości w firmach i przedsiębiorstwach? Czy są widoczne oznaki jej ograniczania?

- Jakie wnioski dotyczące charakteru przedsiębiorczości rozwijającej się w konkretnym regionie można wyciągnąć na podstawie analizy poszczególnych przypadków rozwoju przedsiębiorstw w gminach?

Celem niniejszego opracowania jest zatem próba identyfikacji czynników wpływających na rozwój przedsiębiorczości w regionie. Na podstawie badań pilotażowych można wskazać czynniki rozwoju przedsiębiorstw i firm działających w bliskim otoczeniu Tarnowa. Analizy przypadków umożliwią dokonanie uogólnień i weryfikację hipotez dotyczących możliwości rozwoju przedsiębiorczości firm w gminach okalających Tarnów.

\section{Tarnów jako ośrodek wspierania aktywności mieszkańców w działalności gospodarczej}

Lokalizacja Tarnowa na skrzyżowaniu ważnych europejskich szlaków handlowych jest jedną z jego najmocniejszych stron umożliwiających rozwój przedsiębiorczości. Międzynarodowa trasa E4 (Zgorzelec - Wrocław - Katowice - Kraków - Tarnów - Rzeszów - Medyka) krzyżuje się w mieście z szosą krajową Warszawa - Kielce - Nowy Sącz. Najbliższe lotniska międzynarodowe znajdują się w odległości około 80 km od Tarnowa, w Balicach pod Krakowem i w Jasionce pod

${ }^{1}$ W badaniach uczestniczyli studenci: J. Burzawa, R. Mroczek, T. Kluza. 
Rzeszowem. W bezpośrednim sąsiedztwie miasta będzie przebiegać autostrada. Węzeł oraz zjazd z autostrady, zlokalizowane w pobliżu północno-zachodniej części Tarnowa, przyczynią się do lepszej dostępności miasta. Od południowej strony bezpiecznie i szybko można się dostać do centrum lub ominąć je dzięki niedawno wybudowanej południowej obwodnicy. Atutami Tarnowa są tranzytowe położenie i bliskość przejść granicznych. Od granicy z Ukrainą dzieli Tarnów $180 \mathrm{~km}$, od granicy ze Słowacją - $100 \mathrm{~km}$, od granicy z Niemcami - $500 \mathrm{~km}$. Znaczenie Tarnowa określa jego centralne położenie w Małopolsce, ułatwiające dostęp do rynków w tej części kraju.

Lokalny klimat inwestycyjny to najważniejszy czynnik wpływający na rozwój przedsiębiorczości. Składają się nań: pomoc władz miasta i instytucji biznesowych w zakresie doradztwa i usług dla przedsiębiorców, pomoc w zakresie finansowania działalności gospodarczej i inwestycyjnej oraz miejscowy system udogodnień podatkowych w formie m.in. niższych podatków od nieruchomości i opłat za dzierżawę terenu. Ważną inicjatywą wspierającą przedsiębiorczość jest tworzenie specjalnych stref ekonomicznych, w których stosowane są różne formy udogodnień mających na celu ułatwienie chętnym założenia i prowadzenia działalności gospodarczej.

W ramach lokalnych programów Powiatowy Urząd Pracy oraz Urząd Miasta Tarnowa przygotowały program dla bezrobotnych pod nazwą Mikroinkubator Przedsiębiorczości. Jego celem jest stworzenie sprzyjających warunków powstawania i rozwoju małych firm. W ramach programu mogą być organizowane firmy usługowe, wytwórcze, usługowo-handlowe i handlowe. Uczestnicy programu mogą skorzystać bezpłatnie z pomocy w zakresie:

- indywidualnego poradnictwa dotyczącego ogólnych zasad tworzenia własnej firmy i oceny szans powodzenia przedsięwzięcia;

- doradztwa w zakresie przepisów podatkowych oraz ubezpieczeń społecznych i zdrowotnych,

- pożyczek udzielanych w ramach Funduszu Pracy na rozpoczęcie działalności gospodarczej;

- możliwości wynajmu na preferencyjnych warunkach finansowych lokali położonych na terenie miasta Tarnowa, będących własnością urzędu miasta. Preferencje obejmują zniżki od stawki wywoławczej czynszu: w pierwszym roku działalności-75\%,w drugim roku-50\%, w trzecim roku-25\%;

- jednorazowe dotacje na rozpoczęcie działalności gospodarczej, w tym na pokrycie kosztów pomocy prawnej, konsultacji i doradztwa w wysokości nie większej niż pięciokrotne przeciętne wynagrodzenie ${ }^{2}$.

Na uwagę zasługuje opracowany w Urzędzie Miasta Tarnowa projekt pod nazwą Kompleksowa Obsługa Inwestora, skierowany do przedsiębiorców. Wychodzi on naprzeciw potrzebie tworzenia jak najmniej skomplikowanych procedur postępowania administracyjnego $\mathrm{w}$ sprawach związanych z działalnością gospodarczą, zarówno przedsiębiorców lokalnych, jak i inwestorów zewnętrznych. Program obejmuje:

- inwestycje pozwalające na stworzenie co najmniej piętnastu nowych stałych miejsc pracy;

- inwestycje związane z powstawaniem nowych lub modernizacją i adaptacją istniejących obiektów w rozumieniu prawa budowlanego;

- inwestycje związane z wprowadzaniem nowoczesnych technologii.

W Tarnowie rozwój przedsiębiorczości jest wspierany przez funkcjonowanie specjalnej strefy ekonomicznej. Tarnowski Klaster Przemysłowy „Plastikowa Dolina” S.A. jest podstrefą Specjalnej Strefy Ekonomicznej w Krakowie. Liczy 39,07 ha terenu w pełni uzbrojonego w media. Celem przedsięwzięcia było stworzenie warunków zachęcających przedsiębiorców interesujących się branżą chemiczną do lokalizacji nowych zakładów produkcyjnych w Tarnowie.

${ }^{2}$ Mikroinkubator przedsiębiorczości, http://www.tarnow.pl/biznes w tarnowie/inkubator/index.php, 11.09.2001 r. 
Nowym projektem, przeznaczonym dla osób, które chcą prowadzić własną działalność gospodarcza, jest program skierowany do wszystkich mieszkańców woj. małopolskiego pod hasłem „Winnice Małopolski”. Jest to program Małopolskiej Agencji Rozwoju Regionalnego.

\section{Organizacja usług i doradztwa wspierającego rozwój małych i średnich przedsiębiorstw w Tarnowie i jego okolicach}

Do najważniejszych instytucji wpierających przedsiębiorczość w otoczeniu Tarnowa możemy zaliczyć: Izbę Przemysłowo-Handlową, Wszechnicę Edukacyjna, Małopolski Instytut Samorządu Terytorialnego i Administracji, Tarnowską Agencję Rozwoju Regionalnego, Polską Agencję Rozwoju Przedsiębiorczości, Izbę Rzemieślniczą Małej i Średniej Przedsiębiorczości, Koło Terenowe Polskiego Stowarzyszenia Chrześcijańskich Przedsiębiorców, Ośrodek Innowacji NOT, Krajowy System Usług dla Małych i Średnich Przedsiębiorstw, Korporację Ubezpieczeń Kredytów Eksportowych.

- Izba Przemysłowo-Handlowa w Tarnowie działa od 1992 r. jako Samorząd Gospodarczy, który na zasadzie dobrowolności zrzesza podmioty gospodarcze z dawnego woj. tarnowskiego. Do Izby należą małe i średnie firmy prowadzące działalność gospodarczą w sferze produkcji, handlu i usług. Do zadań Izby należą: reprezentowanie interesów firm członkowskich, promowanie gospodarki regionu tarnowskiego, kształcenie zawodowe poprzez organizowanie szkoleń, kursów, rozpowszechnianie informacji gospodarczej, kojarzenie podmiotów gospodarczych, wydawanie katalogów, organizowanie targów, konkursów i misji gospodarczych, integrowanie członków Izby oraz kształtowanie i upowszechnianie zasad etyki w biznesie. Poprzez taki zakres zadań Izba wpływa na kształtowanie gospodarki na terenie miasta, gminy i powiatu. ${ }^{3}$

- Tarnowska Agencja Rozwoju Regionalnego jest członkiem Krajowego Systemu Usług - sieci regionalnych ośrodków wspierania biznesu, świadczących usługi doradcze, szkoleniowe, informacyjne, finansowe i inne małym i średnim przedsiębiorstwom. TARR świadczy usługi doradczo-szkoleniowe firmom tarnowskim w zakresie marketingu i sprzedaży, zarządzania zasobami ludzkimi, finansów, podatków itd. Uruchomił również Tarnowski Inkubator Przedsiębiorczości, którego celem jest wspieranie powstających i istniejących przedsiębiorstw poprzez udostępnianie taniej powierzchni lokalowej oraz pakietu bezpłatnego doradztwa biznesowego. ${ }^{4} \mathrm{~W}$ ramach TARR funkcjonuje Fundusz Poręczeń Kredytowych, skierowany przede wszystkim do mikro- oraz małych i średnich przedsiębiorców. Pomoc finansowa udzielana jest drobnym przedsiębiorcom niezależnie od fazy rozwoju, począwszy od założenia po jej funkcjonowanie i rozwój. Dotyczy przedsiębiorstw, które znajdują się na terenie powiatu tarnowskiego i powiatów sąsiednich. Fundusz udziela poręczeń kredytowych małym i średnim przedsiębiorstwom za pośrednictwem banków i innych instytucji finansujących.

- Izba Rzemieślnicza Małej i Średniej Przedsiębiorczości w Tarnowie udziela pomocy instruktażowej i doradczej, zwłaszcza w odniesieniu do problemów prawnych, podatkowych, ekonomicznych, finansowych oraz zasad bezpieczeństwa i higieny pracy. Jej zadaniami są również promocja i marketing wyrobów oraz usług małych i średnich przedsiębiorstw. Izba udziela pomocy zrzeszonym w niej organizacjom przy urządzaniu wystaw, giełd, targów i konkursów. ${ }^{5}$

- Koło Terenowe Polskiego Stowarzyszenia Chrześcijańskich Przedsiębiorców. Do podstawowych zadań Stowarzyszenia należy reprezentowanie przedsiębiorców i pracodawców

${ }^{3}$ Izba Przemystowo-Handlowa w Tarnowie, http://www.chamber-tamow.com.pl/izba, 12.06.2006 r.

${ }^{4}$ Tarnowska Agencja Rozwoju Regionalnego, http://www.tarr.tarnow.pl/index.php=tarr/informacje, 12.06.2006 r.

${ }^{5} I z b a$ Rzemieślnicza oraz Matej i Średniej Przedsiębiorczości, http://www.tarnow.pl/biznes_w_tarnowie, 12.06.2006 r. 
deklarujących wiarę chrześcijańską, a także poradnictwo prawne, marketingowe itp., działalność charytatywna i kulturalna. Z inicjatywy Stowarzyszenia przyjeżdżają do Tarnowa holenderscy specjaliści w dziedzinie zarządzania i pomagają w prowadzeniu małego i średniego biznesu ${ }^{6}$.

- Ośrodek Innowacji NOT w Tarnowie świadczy usługi doradcze w zakresie pozyskiwania funduszy Unii Europejskiej. Dotychczas z jego usług skorzystało 85 firm. Ośrodek szkoli przedsiębiorców oraz rolników prowadzących działalność agroturystyczną; współpracuje z gminami oraz Towarzystwem Agrarnym w Tarnowie ${ }^{7}$.

- Małopolski Instytut Samorządu Terytorialnego i Administracji posiada akredytację Krajowego Systemu Usług dla Małych i Średnich Przedsiębiorstw w zakresie usług doradczych i informacyjnych dla przedsiębiorców. Ma wiele propozycji dla przedsiębiorców, m.in. jest wykonawcą projektów Polskiej Agencji Rozwoju Przedsiębiorczości: „Wstęp do jakości”, „Przygotowanie do działania na rynku europejskim”, „Program Rozwoju Przedsiębiorstw” i „Program Rozwoju Przedsiębiorstw Eksportowych”.

Prowadzący działalność gospodarczą lub zamierzający ją rozpocząć mogą także skorzystać z pomocy instytucji ogólnopolskich mających oddziały w Tarnowie: Polskiej Agencji Rozwoju Przedsiębiorczości, Krajowego Systemu Usług dla Małych i Średnich Przedsiębiorstw oraz Korporacji Ubezpieczeń Kredytów Eksportowych ${ }^{8}$. Do głównych zadań PARP należą: wspieranie rozwoju sektora małej i średniej przedsiębiorczości, rozwój eksportu, rozwój regionalny, wykorzystanie nowych technik oraz technologii, tworzenie nowych miejsc pracy oraz przeciwdziałanie bezrobociu. PARP prowadzi również Krajowy System Usług dla Małych i Średnich Przedsiębiorstw.

\section{Przedsiębiorczość w Tarnowie oraz w wybranych gminach w jego okolicy}

Wśród tarnowskich podmiotów gospodarczych przeważa sektor prywatny. Największa liczba podmiotów gospodarczych została zarejestrowana w 2003 r. Liczbę podmiotów zarejestrowanych w 2005 r. według sekcji Polskiej Klasyfikacji Działalności (PKD) przedstawia tab. 1.

Tab. 1. Liczba jednostek gospodarczych zarejestrowanych w Tarnowie (według wybranych sekcji PKD) w 2005 r.

\begin{tabular}{|c|l|c|}
\hline Lp. & \multicolumn{1}{|c|}{ Sekcja } & $\begin{array}{c}\text { Liczba zarejestrowanych } \\
\text { jednostek gospodarczych }\end{array}$ \\
\hline 1. & $\begin{array}{l}\text { Handel detaliczny i hurtowy oraz naprawy pojazdów samocho- } \\
\text { dowych, motocykli, artykułów użytku osobistego i domowego }\end{array}$ & 3768 \\
\hline 2. & $\begin{array}{l}\text { Obsługa nieruchomości, wynajem i usługi związane z prowa- } \\
\text { dzeniem działalności gospodarczej }\end{array}$ & 1841 \\
\hline 3. & Przetwórstwo przemysłowe & 919 \\
\hline 4. & Budownictwo & 847 \\
\hline 5. & Transport, gospodarka magazynowa i łączność & 768 \\
\hline 6. & Pośrednictwo finansowe & 489 \\
\hline 7. & Hotele i restauracje & 212 \\
\hline 8. & Rolnictwo, łowiectwo i leśnictwo & 69 \\
\hline
\end{tabular}

Źródło: dane Urzędu Miasta Tarnowa

${ }^{6}$ Polskie Stowarzyszenie Chrześcijańskich Przedsiębiorców, http://www.wsd.tarnow.pl/stowarzyszenia, 12.06.2006 r.

${ }^{7}$ Sieć Ośrodków Innowacji NOT, http://innowacje.not.org.pl/437-42b986b21e5f6.htm, 14.06 .2006 r.

${ }^{8}$ Por. Moduly tematyczne, http://www.mistia.org.pl/mistia/index2.htm, 13.06.2006 r. 
W Tarnowie najwięcej podmiotów gospodarczych zajmuje się handlem detalicznym i hurtowym, naprawami pojazdów samochodowych, motocykli, artykułów użytku osobistego i domowego. Drugie miejsce zajmują: obsługa nieruchomości, wynajem i usługi związane z prowadzeniem działalności gospodarczej. Trzecim popularnym rodzajem działalności gospodarczej jest przetwórstwo przemysłowe.

W gminie Pilzno przedsiębiorczość od dawna jest związana z rzemiosłem, które mimo przemian gospodarczych i kryzysów politycznych przetrwało i stanowi podstawę współczesnej przedsiębiorczości. Przykładem mogą być zakłady, które powstały w drugiej połowie XX w.: Piekarnia Drobińskich, Zakład stolarski „Limba” i Cukiernia D. Desoń.

Rozwój sektora przemysłu prywatnego to szansa rozwoju miasta i gminy. W 1998 r. w gminie Pilzno zanotowano 620 tzw. podmiotów gospodarczych, 31.12.2004 r. prowadziło działalność 701 podmiotów gospodarczych, a rok później zarejestrowano 778 przedsiębiorstw, co daje 2244 miejsca pracy w gminie, w tym 1428 w samym Pilźnie.

Podobnie jak w całym kraju, w gminie Pilzno po 1990 r. wiele zakładów rzemieślniczych przekształciło się w małe i średnie przedsiębiorstwa prywatne, które dają zatrudnienie miejscowej ludności. Skoncentrowane są w samym Pilźnie, gdzie infrastruktura jest najlepiej rozwinięta, a zapotrzebowanie na usługi - największe. Poza Pilznem, na terenach wiejskich, przedsiębiorcy działaja jednoosobowo.

Na terenie gminy Pilzno w 2005 r. prowadziło działalność 778 podmiotów gospodarczych.

Tab. 2. Liczba podmiotów gospodarczych w gminie Pilzno według branż

\begin{tabular}{|r|l|c|c|}
\hline Lp. & \multicolumn{1}{|c|}{ Rodzaj branży } & $\begin{array}{c}\text { Liczba podmiotów } \\
\text { gospodarczych } \\
\text { w 2004 r. }\end{array}$ & $\begin{array}{c}\text { Liczba podmiotów } \\
\text { gospodarczych } \\
\text { w 2005 r. }\end{array}$ \\
\hline 1. & Handel & 247 & 231 \\
\hline 2. & Produkcja wyrobów metalowych & 25 & 24 \\
\hline 3. & Produkcja i naprawa maszyn rolniczych & 2 & 2 \\
\hline 4. & Przetwórstwo mięsne & 1 & 1 \\
\hline 5. & Piekarnictwo i cukiernictwo & 5 & 5 \\
\hline 6. & Produkcja mebli i wyrobów z drewna & 30 & 31 \\
\hline 7. & Gastronomia i hotelarstwo & 15 & 16 \\
\hline 8. & Transport & 108 & 115 \\
\hline 9. & Naprawy samochodów & 27 & 31 \\
\hline 10. & Inne & 241 & 253 \\
\hline
\end{tabular}

Źródło: dane Urzędu Gminy Pilzno

Wśród podmiotów gospodarczych w latach 2004 i 2005 przeważały przedsiębiorstwa zajmujące się handlem, transportem i produkcją mebli oraz wyrobów z drewna. W handlu panuje tendencja spadkowa. Wysokie czynsze oraz duża konkurencja sprawiają, że na rynku utrzymują się tylko ci przedsiębiorcy, którzy potrafią znaleźć odpowiednie źródła zaopatrzenia, dostosować działalność do potrzeb rynku i umiejętnie organizować dystrybucję wyrobów.

W gminie Skrzyszów w końcu 2005 r. zarejestrowanych było 578 podmiotów gospodarczych (tab. 3). Najwięcej podmiotów prowadzi działalność handlową, wiele jest przedsiębiorstw budowlanych i transportowych. 
Tab. 3. Liczba podmiotów gospodarczych w gminie Skrzyszów według branż

\begin{tabular}{|c|l|c|}
\hline Lp. & \multicolumn{1}{|c|}{ Branża } & $\begin{array}{c}\text { Liczba podmiotów } \\
\text { gospodarczych w 2005 r. }\end{array}$ \\
\hline 1. & Handel & 218 \\
\hline 2. & Gastronomia & 3 \\
\hline 3. & Piekarnictwo & 2 \\
\hline 4. & Cukiernictwo & 2 \\
\hline 5. & Przetwórstwo mięsne & 2 \\
\hline 6. & Transport & 30 \\
\hline 7. & Budownictwo & 95 \\
\hline 8. & Stolarstwo & 12 \\
\hline 9. & Inne & 214 \\
\hline
\end{tabular}

Źródło: dane Urzędu Gminy Skrzyszów

Najpoważniejszą barierą rozwoju przedsiębiorstw jest brak środków finansowych na modernizację. Wśród małych i średnich firm utrzymuje się tendencja finansowania rozwoju przede wszystkim z własnych środków. Taką postawę wywołują uwarunkowania makroekonomiczne, które określają rynkowe warunki funkcjonowania przedsiębiorstw na terenie gminy, oraz czynniki wewnętrzne, przede wszystkim wielkość majątku przedsiębiorstwa. Trudna sytuacja spowodowana jest spadkiem zapotrzebowania na usługi i produkty.

Pod względem rozwoju technologicznego małe i średnie przedsiębiorstwa pozostają w tyle za dużymi firmami. Wprowadzenie do produkcji nowego lub zmodernizowanego wyrobu czy nowej lub zmodernizowanej technologii wiąże się z poważnymi wydatkami, zbyt wysokimi, jak na możliwości małych i średnich firm.

Małe przedsiębiorstwa cechuje niedostateczny poziom wiedzy o prowadzeniu przedsiębiorstwa oraz umiejętności praktycznego jej zastosowania. Około 50\% małych i średnich przedsiębiorstw w gminie ma dostęp do internetu, ale nieliczne to wykorzystują.

\section{Czynniki wpływające na rozwój przedsiębiorczości w rejonie Tarnowa}

Czynniki zidentyfikowane $\mathrm{w}$ trakcie badań pilotażowych, które stwarzają dogodne warunki dla rozwoju przedsiębiorczości w Tarnowie, to:

- dogodne położenie Tarnowa jako ośrodka rozwoju przedsiębiorczości w regionie; przedsięwzięcia zmierzające do poprawy warunków dostępności komunikacyjnej; bliskość Krakowa i Rzeszowa;

- lokalny klimat wokół rozwoju przedsiębiorczości; wyniki analizy upoważniają do stwierdzenia, że w rejonie Tarnowa stworzono dogodne warunki inwestycyjne rozwoju małych i średnich przedsiębiorstw. Działa dziesięć organizacji zajmujących się doradztwem i usługami w tej dziedzinie. Na pobudzenie przedsiębiorczości w latach 2003-2005 przeznaczono ponad 700 tys. zł. Stworzono system udzielania pożyczek finansowych i zniżek przy wynajmie lokali przeznaczonych na działalność gospodarczą. W wyniku tych działań - na liście najlepszych miejsc do inwestowania w Polsce w kategorii miast powyżej 100 tys. mieszkańców, Tarnów zajmuje siódme miejsce; 
- tradycje w przemyśle chemicznym, maszynowym, szklarskim; bogate tradycje rzemieślnicze zarówno w Tarnowie, jak i w gminach otaczających miasto;

- utworzenie Tarnowskiego Klastra Przemysłowego „Plastikowa Dolina” oraz Małopolskiego Rynku Hurtowego;

- rozwój sieci szkolnictwa wyższego opartego na dorobku i kadrze uczelni krakowskich;

- atrakcje turystyczne Tarnowa i okolic;

- cykliczne tradycyjne imprezy kulturalne, targowe i wystawiennicze.

\section{Rodzaje działalności gospodarczej w gminach}

W gminach, które podlegały analizie, przeważają przedsiębiorstwa zajmujące się handlem detalicznym i hurtowym, naprawą pojazdów samochodowych, motocykli oraz artykułów użytku osobistego i domowego. W dalszej kolejności należy wymienić obsługę nieruchomości, wynajem i usługi związane z prowadzeniem działalności gospodarczej i przetwórstwa przemysłowego. W gminie Pilzno przeważają przedsiębiorstwa handlowe, transportowe oraz produkujące meble i wyroby z drewna. W gminie Skrzyszów najwięcej podmiotów prowadzi działalność handlową; liczne są przedsiębiorstwa budowlane i transportowe.

Najbardziej zróżnicowana działalność występuje w Tarnowie, gdzie przeważają przedsiębiorstwa świadczące usługi oraz zajmujące się przetwórstwem przemysłowym. W otoczeniu Tarnowa zdecydowanie przeważa aktywność w handlu, transporcie, budownictwie i rzemiośle.

\section{Podsumowanie}

Badania, o których mowa, miały charakter pilotażowy. Głównym ich celem była analiza rozwoju przedsiębiorczości w gminach położonych w pobliżu Tarnowa. Obecnie prowadzone są badania nad rozwojem przedsiębiorczości w gminach: Brzesko, Lisia Góra, Tuchów, Wierzchosławice, Wojnicz i Żabno. W toku dalszych badań będzie można w sposób kompleksowy podejść do zjawiska przedsiębiorczości w całym rejonie.

Należy przyjąć, że rodzajów przedsiębiorczości jest tyle, ile badanych firm. Widoczne są charakterystyczne dla konkretnych rejonów typy inicjatyw przedsiębiorczych wyróżnianych na podstawie rodzaju działalności oraz skali przedsięwzięć. Niewielka liczba przebadanych gmin nie upoważnia jednak do wysuwania daleko idących wniosków. Największą trudność w rozwoju przedsiębiorczości - jak się wydaje w świetle przeprowadzonych badań - sprawiają: planowanie, motywowanie i systematyzacja działań przedsiębiorczych oraz niedostateczny kapitał społeczny i intelektualny. Trudności wynikają także z polityki państwa, które pomimo zapewnień o promocji przedsiębiorczości, nadal nie oferuje dogodnych warunków do jej rozwoju.

\section{Enterprise Development in the Area of Tarnow}

The author introduces the results of carried out in Tarnow and its adjoining area a pilotage research into the enterprise development. The analysis concerns the factors that decide about enterprise development in this area, and presents a range of activities to which the inhabitants show the biggest commitment. In the final part conclusions of the research up to the present time are presented. 